\title{
Revision of the genus Cyathus (Basidiomycota) from the herbaria of northeast Brazil
}

\author{
Cruz RHSF ${ }^{1}$, Assis $\mathrm{NM}^{2}$, Silva $\mathrm{MA}^{3}$ and Baseia $\mathrm{IG}^{4}$ \\ ${ }^{1}$ Programa de Pós-Graduação em Sistemática e Evolução, Centro de Biociências, Universidade Federal do Rio \\ Grande do Norte, Avenida Senador Salgado Filho, 3000, Natal-RN 59.078-970 Brazil, rhudsoncruz@yahoo.com.br \\ ${ }^{2}$ Departamento de Botânica e Zoologia, Centro de Biociências, Universidade Federal do Rio Grande do Norte, \\ Avenida Senador Salgado Filho, 3000, Natal-RN 59.078-970 Brazil,nathalia.assis@outlook.com \\ ${ }^{3}$ Departamento de Micologia, Universidade Federal de Pernambuco, Avenida Professor Moraes Rego 1235, Recife-PE \\ 50.670-901 Brazil, cidoka83@gmail.com \\ ${ }^{4}$ Departamento de Botânica e Zoologia, Centro de Biociências, Universidade Federal do Rio Grande do Norte, \\ Avenida Senador Salgado Filho, 3000, Natal-RN 59.078-970 Brazil, iuribaseia@ gmail.com
}

Cruz RHSF, Assis NM, Silva MA, Baseia IG 2014 - Revision of the genus Cyathus (Basidiomycota) from the herbaria of northeast Brazil. Mycosphere 5(4), 531-540, Doi 10.5943/mycosphere/5/4/5

\begin{abstract}
Seventy exsiccates of the genus Cyathus deposited in JPB, UESC, URM and UFRN herbaria were studied and nine species were identified: Cyathus badius, C. berkeleyanus, C. earlei, C. gracilis, C. limbatus, C. pallidus, C. poeppigii, C. setosus and C. striatus. Cyathus berkeleyanus and $C$. poeppigii are recorded for the first time for northeastern Brazil. Descriptions, taxonomic remarks and illustrations of the studied material are presented.
\end{abstract}

Key words - herbarium collection - Nidulariaceae - Gasteromycetes - taxonomic review

\section{Introduction}

The genus Cyathus Haller belongs to the family Nidulariaceae, included in the agaricoid clade of Basidiomycota (Matheny et al. 2006), and is morphologically characterized by a threelayered bell or vase-shaped basidiomata with lenticular structures (peridioles) fixed to the inner wall by the funicular cord (Brodie 1975). The genus currently has 45 species (Kirk et al. 2008), with cosmopolitan distribution in temperate and tropical countries, but rarely found in polar or glacial regions (Brodie 1975).

The mycological collections deposited in academic herbaria are important for providing information and biological material for research, cataloguing and reporting to society (Fogel 1998). Through the deposited material it is possible to build a reference database for easy identification, allowing the "discovery" of species hitherto not described (Brock et al. 2008). Thus, this study aimed to review the genus Cyathus in JPB, UESC, URM and UFRN herbaria, including all species deposited in Northeastern Brazilian except those described at the species level in the URM herbarium, which Trierveiler-Pereira \& Baseia (2009) have recently revised, and materials from the UFRN herbarium described by Cruz et al. (2012), thereby increasing knowledge of this genus in Brazil. 


\section{Materials \& Methods}

Seventy exsiccates of dried Cyathus specimens were obtained from collections in JPB, UESC, URM and UFRN herbaria. These were studied in the Taxonomy Laboratory, Department of Mycology, Federal University of Pernambuco (UFPE), and Laboratory of Fungal Biology, Department of Botany, Ecology and Zoology, Federal University of Rio Grande do Norte (UFRN). The Herbarium acronyms follow Thiers (2013).

Analyses were performed following methodologies proposed by Brodie (1975) and Zhao et al. (2008). Macroscopic analyses were conducted with the aid of a stereomicroscope. The colors were coded according to Kornerup \& Wanscher (1978). Microscopic analyses of the basidiospores were carried out with the aid of an optical microscope, using portions of the peridioles mounted in $3 \% \mathrm{KOH}$ solution. Based on Zhao et al. (2008), the average length (L) and width (W) of the spores were analyzed, as well as the mean ratio between the length and width $\left(\mathrm{Q}_{\mathrm{m}}\right)$.

\section{Results and Discussion}

\section{Taxonomy}

Cyathus badius Kobayasi, Bot. Mag., Tokyo 51: 755 (1937)

Figs $1 \mathrm{~A}-1 \mathrm{C}$

Peridium infundibuliform to campanulate, $8-11 \mathrm{~mm}$ high, 4-6 mm wide at the mouth, not expanding at the top or tapering abruptly at the base; attached to the substrate by a conspicuous dark brown (7F5) emplacement, 3-5 $\mathrm{mm}$ in diameter. Exoperidium hairy, concolor to the emplacement, covered with a $0.4 \mathrm{~mm}$ tomentum, arranged in irregular and rigid tufts; external wall faintly plicate, with $0.3 \mathrm{~mm}$ between folds. Mouth minutely fimbriated, with tomentum $0.2 \mathrm{~mm}$ long, chocolate-colored (6F4). Endoperidium reddish brown (8E5), plicate, $0.5 \mathrm{~mm}$ between folds, slightly shiny, not contrasting with the exterior. Peridioles $1.6-1.9 \times 1.4-1.7 \mathrm{~mm}$, sepia (4F4), 13 per basidioma, circular to irregular in outline. Tunic present, yellowish. Cortex single layered. Basidiospores smooth, hyaline, elliptical, without an apicule, $12-22 \times 7-17 \mu \mathrm{m}(\mathrm{L}=16.92 \mu \mathrm{m}$; W $\left.=9.42 \mu \mathrm{m} ; \mathrm{Q}_{\mathrm{m}}=1.50\right)$, thick walled, 2.5-3.5 $\mu \mathrm{m}$.

Habitat and distribution - Grows in clusters on decaying wood. Known from Japan (Kobayasi 1937), China (Liu \& Li 1989) and Brazil (Cruz et al. 2012).

Material examined - Brazil, Pernambuco, Igarassu, Reserva Ecológica Charles Darwin, 28 May 2010, M.A. Silva \& F. Wartchow, URM 83645.

Notes - This species belongs to group I - olla, defined by Brodie (1975) or pallidum, defined by Zhao et al. (2007). In comparison to C. badius, described originally by Kobayasi, this sample has a slightly narrower mouth (6-8 $\mathrm{mm}$ in the original description, 4-6 $\mathrm{mm}$ here), possibly due to the post-collection storage method. Despite being a species from the URM herbarium, a collection revised by Trierveiler-Pereira \& Baseia in 2009, this material was registered as Cyathus sp., which encouraged us to analyze it. It was recently described as the second world record from the Atlantic Forest in Northeastern Brazil (Cruz et al. 2012), but a more thorough research in the literature showed that the second world record was made for China by Liu \& Li (1989), and that the Brazilian register was the first for the American continent.

Cyathus berkeleyanus (Tul. \& C. Tul.) Lloyd, The Nidulariaceae or 'bird's nest fungi': 19 (1906)

Figs $1 \mathrm{D}-1 \mathrm{~F}$

Peridium campanulate to infundibuliform, 5.7-8.4 $\mathrm{mm}$ high, $4.2-7.7 \mathrm{~mm}$ wide at the mouth, not expanding at the top, but tapering abruptly at the base; attached to the substrate by a small, conspicuous dark brown (8F4) emplacement. Exoperidium hairy, concolor to the emplacement, covered with a $0.4-0.5 \mathrm{~mm}$ tomentum, arranged in irregular and flexible tufts; external wall distinctly plicate, $0.5 \mathrm{~mm}$ between folds. Mouth distinctly fimbriated, with tomentum $0.5-0.75 \mathrm{~mm}$ long, dark brown (8F4). Endoperidium brown (8E7), conspicuously plicate, with $0.5 \mathrm{~mm}$ between folds, slightly shiny, not contrasting with the exterior. Peridioles $2.2 \times 1.7-2.1 \mathrm{~mm}$, black, 11-12 per basidioma, angular in outline. Tunic present, hyaline. Cortex single layered. Basidiospores 
smooth, hyaline, elliptical, without an apicule, 8.9-14 $\times 5-7.6 \mu \mathrm{m}(\mathrm{L}=10.54 \mu \mathrm{m} ; \mathrm{W}=6.73 \mu \mathrm{m}$; $\left.\mathrm{Q}_{\mathrm{m}}=1.59\right)$, thin walled, 1-2.5 $\mu \mathrm{m}$.

Habitat and distribution - Grows in clusters on decaying wood. Known from Jamaica (White 1902), South Africa (Bottomley 1948), West Indies (Brodie \& Dennis 1954), China (Liu 1984) and Mexico (Gómez \& Pérez-Silva 1988). In Brazil it was recorded for the States of Rio de Janeiro (Lloyd 1906, Bononi et al. 1984), São Paulo (Baseia \& Milanez 2001) and Paraná (Meijer 2006).

Material examined - Brazil, Rio Grande do Sul, Santa Maria, Morro do Elefante, 23 June 2006, V.G. Cortez, UFRN-Fungos 1244; Brazil, Pernambuco, Igarassu, Reserva Ecológica Charles Darwin, 04 April 2003, I.G. Baseia, UFRN-Fungos 161; Brazil, Bahia, Jussari, Serra do Teimoso, 19 May 2003, J.L. Bezerra, UESC 288; Brazil, Bahia, Buerarema, Conjunto Camacan, 14 November 2006, J.L. Bezerra, UESC 2022; Brazil, Bahia, Itacaré, Fazenda Canta Galo, 17 May 2002, J.L. Bezerra, UESC 217.

Notes - Species belongs to group VII - striatus, defined by Brodie (1975) or pallidum, defined by Zhao et al. (2007). According to Brodie (1975), this species exhibits variations in size, color, plication and spore length, and the materials analyzed contained slight variations in spore size from those originally described $(6-9 \times 4-7 \mu \mathrm{m}$ in the original description, 8.9-14 $\times 5-7.6 \mu \mathrm{m}$ here). Cyathus berkeleyanus can be easily confused with $C$. pallidus Berk. \& M.A. Curtis, mainly in light-colored samples, due to the shape of the peridium and size of the basidiospores, and also because both species have a single cortex. Except for the collection from Rio Grande do Sul state, described here, this is the first record of $C$. berkeleyanus for Northeastern Brazil.

Cyathus earlei Lloyd, The Nidulariaceae or 'bird's nest fungi': 26 (1906)

Figs 1G-1I

Peridium infundibuliform, 6-11 $\mathrm{mm}$ high, 5-9 $\mathrm{mm}$ wide at the mouth, not expanding at the top or tapering abruptly at the base; attached to the substrate by a conspicuous reddish-brown to dark brown (6F5-7F5) emplacement, 3-5.5 mm in diameter. Exoperidium hairy, bronze to reddish brown (5E5-6F5), covered with a 0.4-0.7 $\mathrm{mm}$ tomentum, arranged in irregular and flexible tufts; external wall smooth to faintly plicate, $0.4-0.5 \mathrm{~mm}$ between folds. Mouth minutely fimbriated, $0.2-$ $0.5 \mathrm{~mm}$ long, concolor to the exoperidium. Endoperidium brownish grey to greyish brown (6D26D3), smooth to faintly plicate, $0.5 \mathrm{~mm}$ between folds, perceptibly bright, contrasting with the exterior. 1-2 mm brownish grey to greyish brown (5F2-8F3) stipe; epiphragm fragile, white to beige, flexible. Peridioles $2-3 \mathrm{~mm} \times(1.5) 2-3 \mathrm{~mm}$, dark grey to brownish grey $(1 \mathrm{~F} 1-8 \mathrm{~F} 2)$, bright, 14-16 per basidioma, irregular, circular or elliptical in outline. Tunic present, hyaline, bronze. Cortex double layered. Basidiospores smooth, hyaline, elliptical to ovoid, without an apicule, 13.97-19.05 × 10.16-12.7 $\mu \mathrm{m}\left(\mathrm{L}=16.28 \mu \mathrm{m} ; \mathrm{W}=11.37 \mu \mathrm{m} ; \mathrm{Q}_{\mathrm{m}}=1.44\right)$, thin walled, 1.27-2.54 $\mu \mathrm{m}$.

Habitat and distribution - Solitary, growing on decaying wood, branches and seeds. Known from Cuba, Hawaii (Lloyd 1906), Puerto Rico, Mexico, the West Indies (Brodie \& Dennis 1954), India (Brodie 1984) and Brazil (Cruz et al. 2012).

Material examined - Brazil, Rio Grande do Norte, Natal, Parque Estadual Dunas do Natal, Peroba trail, 17 July 2010, I.G. Baseia, A.G. Leite, R.H.S.F. Cruz, J.J.S. Oliveira, UFRN-Fungos 1913, UFRN-Fungos 1914, UFRN-Fungos 1915, UFRN-Fungos 1917; Geology trail, 25 April 2009, R.H.S.F. Cruz, B.D.B. Silva, J.J.S. Oliveira, UFRN-Fungos 1043; 26 October 2010, R.H.S.F. Cruz, UFRN-Fungos 1918, UFRN-Fungos 1919, UFRN-Fungos 1920, UFRN-Fungos 1916, UFRN-Fungos 1921; 06 July 2011, R.H.S.F. Cruz, R. Frigo, UFRN-Fungos 1923, UFRNFungos 1924, UFRN-Fungos 1925, UFRN-Fungos 1926, UFRN-Fungos 1927; 27 June 2012, L.D. Xavier, UFRN-Fungos 1922; Brazil, Pernambuco, Recife, Parque Dois Irmãos, 03 October 2010, M.A. Silva, R.F. Melo, URM 83648; Brazil, Paraíba, João Pessoa, Campus I of UFPB, 8 May 1985, V.L.F. Araujo, JPB 9329; 08 May 1991, I.C. Oliveira, JPB 17594; 16 June 1994, I.C. Oliveira, JPB 16372; 8 October 1995, I.G. Baseia, JPB 13224, JPB 13220.

Notes - Belongs to group I - olla, according to Brodie's classification (1975), or to the

pallidum group, according to Zhao et al. (2007); this species is recurrent in Atlantic Forest areas of Northeastern Brazil. Despite having a hairy tomentum, sample URM 83648 was wooly, 

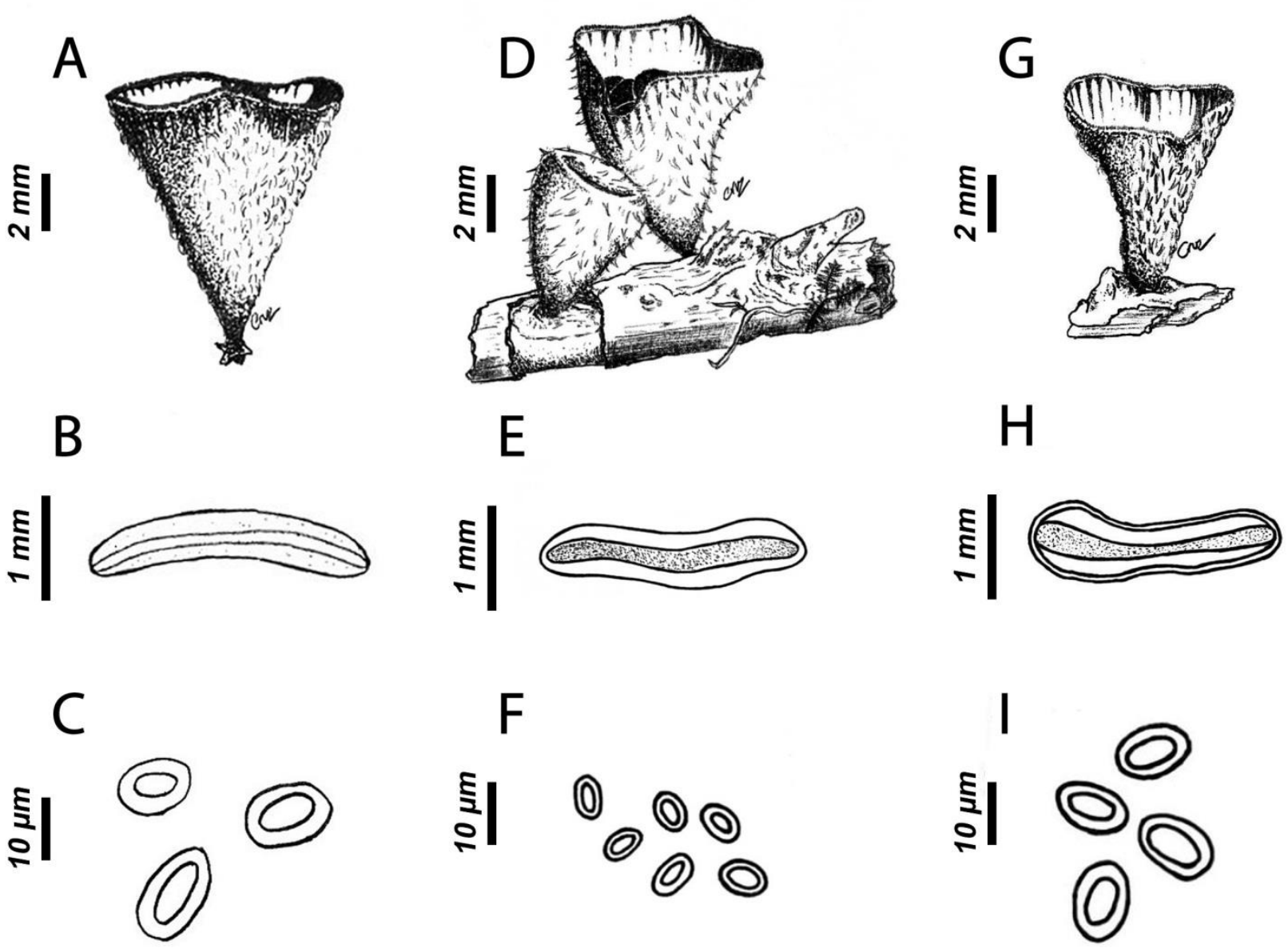

Figs 1 - A-C, Cyathus badius: A, Basidiomata. B, Peridiole with single-layered cortex. C, Basidiospores. D-F, Cyathus berkeleyanus: D, Basidiomata. E, Peridiole with single-layered cortex. F, Basidiospores. G-H, Cyathus earlei: G, Basidiomata. H, Peridiole with double-layered cortex. I, Basidiospores.

probably due to the storage method used in the herbarium. Another sample (UFRN-Fungos 1916) exhibited powdery exoperidium, which, when observed with a stereomicroscope, showed only fragments of wood substrate. Furthermore, sample UFRN-Fungos 1923 displayed an apicule in a few rare spores. A record of Cyathus earlei was recently published for the Northeast by Cruz et al. 2012.

Cyathus gracilis H.J. Brodie, Can. J. Bot. 51 (7): 1393 (1973)

Figs 2A-2C

Peridium infundibuliform, 7-12 $\mathrm{mm}$ high, 5-9 $\mathrm{mm}$ wide at the mouth, not expanding at the top or tapering abruptly at the base; attached to the substrate by a conspicuous emplacement, chocolate brown to dark brown (6F5-8F6), 2.5-6 mm in diameter. Exoperidium hairy, concolor to the emplacement, covered with a $0.7-1 \mathrm{~mm}$ tomentum, arranged in regular and flexible tufts; external wall smooth to faintly plicate, $0.4-0.7 \mathrm{~mm}$ between folds. Mouth minutely fimbriated, $0.1-$ $0.3 \mathrm{~mm}$, chocolate brown to dark brown $(6 \mathrm{~F} 4-8 \mathrm{~F} 6)$. Endoperidium brownish grey to greyish brown (7D2-7F3), smooth to faintly plicate, $0.5-0.75 \mathrm{~mm}$ between folds, slightly bright, not contrasting with the exterior. Stipe 1.5-3 mm length, greyish brown to brownish grey (7E2-6F2); epiphragm white, flexible. Peridioles 1.5-2.5 (3) $\mathrm{mm} \times 1.5-2.5 \mathrm{~mm}$, greyish brown (7F3), 12-18 per basidioma, irregular to circular in outline. Tunic hyaline, bronze. Cortex double layered. Basidiospores smooth, hyaline, elliptical to ovoid, without an apicule, 13.97-19.05 × 10.16-13.97 $\mu \mathrm{m}\left(\mathrm{L}=16.93 \mu \mathrm{m} ; \mathrm{W}=11.43 \mu \mathrm{m} ; \mathrm{Q}_{\mathrm{m}}=1.49\right)$, thin walled $1.27-2.54 \mu \mathrm{m}$. 
Habitat and distribution - Growing in clusters on decaying woods or branches. Known from the Philippines (Brodie 1975), Guam (Brodie 1984) and Brazil for the State of Ceará (Barbosa et al. 2014).

Material examined - Brazil, Rio Grande do Norte, Natal, Parque Estadual Dunas do Natal, Peroba trail, 10 July 2004, I.G. Baseia, P.P.T. Lacerda, UFRN-Fungos 31, UFRN-Fungos 80, UFRN-Fungos 476, UFRN-Fungos 477; 20 June 2009, R.H.S.F. Cruz, UFRN-Fungos 1928; 26 June 2009, E.P. Fazolino, B.D.B. Silva, UFRN-Fungos 1115; 19 April 2010, M.M.B. Barbosa, J.J.S. Oliveira, R.H.S.F. Cruz, UFRN-Fungos 1437, UFRN-Fungos 1438; 13 July 2010, M.M.B. Barbosa, R.H.S.F. Cruz, UFRN-Fungos 1439, UFRN-Fungos 1440; Perobinha trail, 17 July 2010, I.G. Baseia, A.G. Leite, R.H.S.F. Cruz, J.J.S. Oliveira, UFRN-Fungos 1929, UFRN-Fungos 1930, UFRN-Fungos 1931; Brazil, Pernambuco, Buíque, Vale do Catimbau, 30 November 2006, I.G. Baseia, UFRN-Fungos 1112; Pedra Solteira trail, 08 December 2006, T.B. Gibertoni, UFRNFungos 406, UFRN-Fungos 1290, UFRN-Fungos 1292; 11 December 2006, T.B. Gibertoni, UFRN-Fungos 397; Brazil, Bahia, Wenceslau Guimarães, Estação Ecológica, 14 April 2008, J. Pereira, UESC 1393.

Notes - Cyathus gracilis belongs to the homonym group, according to Brodie's classification (1975) or the pallidum group, according to Zhao et al. (2007). Commonly identified as $C$. pedicellatus H.J. Brodie in Brazilian herbaria because of the pedicel exhibited in a number of samples, this species is distinguished by plications (distinctly plicate in the endo and exoperidium in $C$. pedicellatus, smooth to faintly plicate in $C$. gracilis), which places $C$. pedicellatus in group VI - poeppigii in Brodie's monography (1975) or in the striatum group of Zhao et al. (2007). Other characteristics are the subhomogeneous double layered cortex in $C$. pedicellatus (rather than clearly double in $C$. gracilis), and spore size $(24-27 \times 12-14 \mu \mathrm{m}$ in $C$. pedicellatus and 13.97-19.05 $\times$ $10.16-13.97 \mu \mathrm{m}$ in $C$. gracilis [ $20 \times 10 \mu \mathrm{m}$ in type species]). According to the original description, C. gracilis exhibits concolor endoperidium and exoperidium, or slightly lighter in the internal portion, in addition to a delicate tunic, which was also found in this sample. Recorded recently in the semi-arid region of Northeastern Brazil (Barbosa et al. 2014), this is the first record of $C$. gracilis for the Atlantic rainforest.

Cyathus limbatus Tul. \& C. Tul., Ann. Sci. Nat., Bot., sér. 3 1: 78 (1844)

Figs 2D-2F

Peridium infundibuliform, 7.5-12 $\mathrm{mm}$ high, 5-10 $\mathrm{mm}$ wide at the mouth, not expanding at the top or tapering abruptly at the base; attached to the substrate by a conspicuous reddish brown (6F5-9F6) emplacement, 1.5-4 $\mathrm{mm}$ in diameter. Exoperidium hairy, occasionally wooly, concolor to the emplacement, covered with a $0.5-1 \mathrm{~mm}$ tomentum, arranged in irregular and flexible tufts; external wall conspicuously plicate, $0.75-1 \mathrm{~mm}$ between folds. Mouth minutely fimbriated, $0.1-0.4$ $\mathrm{mm}$, chocolate brown to reddish brown (6F4-9F6). Endoperidium greyish brown (9F3), conspicuously plicate, $0.75-1 \mathrm{~mm}$ between folds, slightly bright in some basidiomata, not contrasting with the exterior, $1.5-2 \mathrm{~mm}$ brownish grey to dark brown $(6 \mathrm{~F} 2-7 \mathrm{~F} 4)$ stipe; epiphragm white, flexible. Peridioles (1.5) 2-2.5 (3) $\mathrm{mm} \times(1.5)$ 2-2.5 (3) $\mathrm{mm}$, grey to greyish brown (9F16F3), 12-16 per basidioma, circular to irregular in outline. Tunic indistinct. Cortex double layered. Basidiospores smooth, hyaline, elliptical to ovoid, apicule present in some spores, 15.24-21.59 $\times$ 10-12.7 $\mu \mathrm{m}\left(\mathrm{L}=18.88 \mu \mathrm{m} ; \mathrm{W}=11.60 \mu \mathrm{m} ; \mathrm{Q}_{\mathrm{m}}=1.63\right)$, thick walled 2-3.8 $\mu \mathrm{m}$.

Habitat and distribution - Growing in abundant clusters on decaying branches. Known from British Guiana, India, China, Hawaiian islands, Pacific islands, and various African and South American countries (Brodie 1975).

Material examined - Brazil, Rio Grande do Norte, Natal, Parque Estadual Dunas do Natal, Peroba trail, 09 July 2004, M.M.B. Barbosa, P.P.T. Lacerda, I.G. Baseia, UFRN-Fungos 475; 10 July 2004, I.G. Baseia, P.P.T. Lacerda, UFRN-Fungos 03, UFRN-Fungos 30, UFRN-Fungos 120; 10 October 2004, P.P.T. Lacerda, UFRN-Fungos 1932; 19 October 2005, I.G. Baseia, P.P.T. Lacerda, UFRN-Fungos 1123; 18 June 2006, I.G. Baseia, P.P.T. Lacerda, UFRN-Fungos 1124; 20 June 2009, R.H.S.F. Cruz, UFRN-Fungos 1911; Geology trail, 07 July 2009, R.H.S.F. Cruz, J.J.S. Oliveira, M.I.M. Concentino, UFRN-Fungos 1122; Perobinha trail, 17 July 2010, I.G. Baseia, 

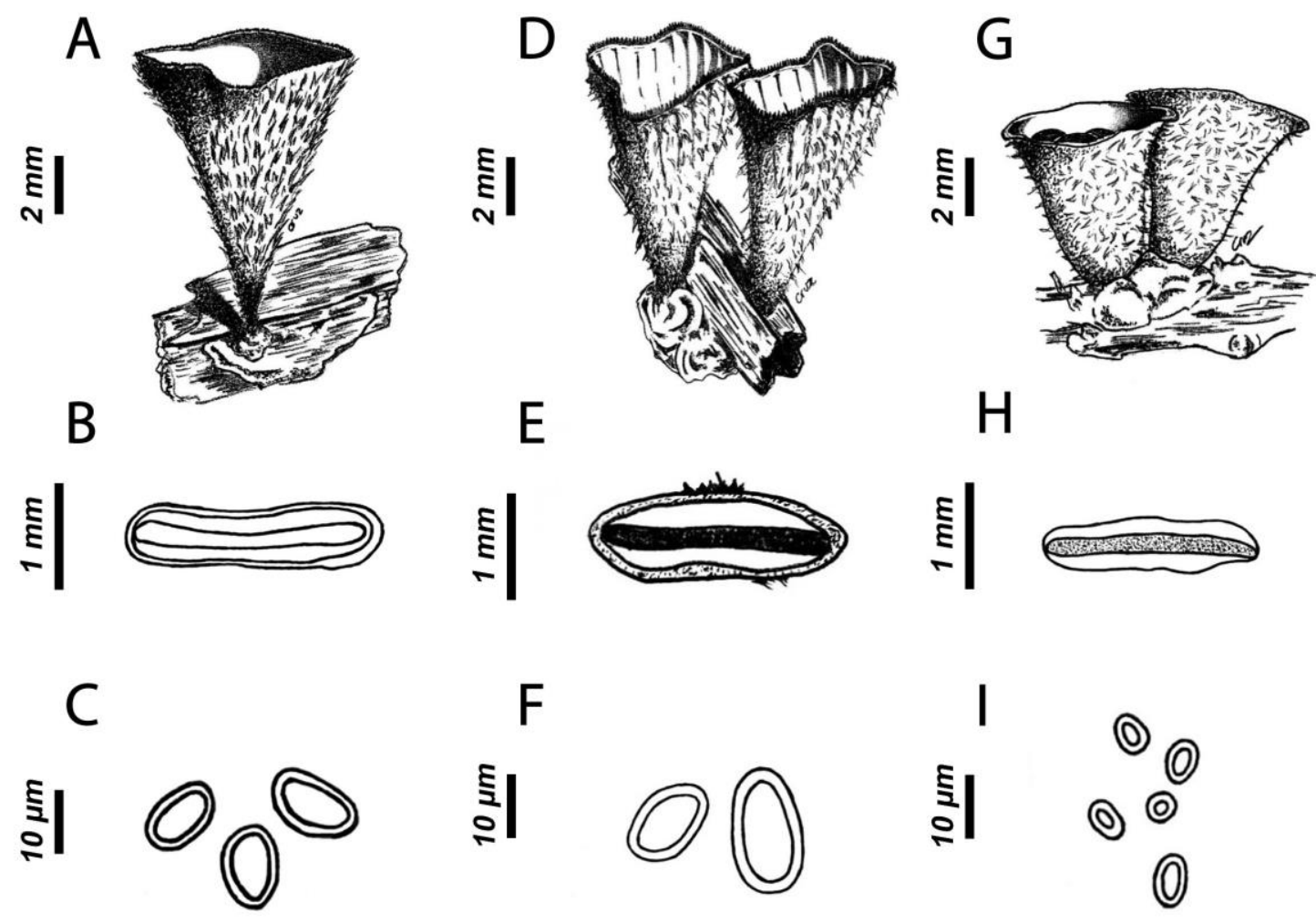

Figs 2 - A-C, Cyathus gracilis: A, Basidiomata. B, Peridiole with double-layered cortex. C, Basidiospores. D-F, Cyathus limbatus: D, Basidiomata. E, Peridiole with double-layered cortex. F, Basidiospores. G-H, Cyathus pallidus: G, Basidiomata. H, Peridiole with single-layered cortex. I, Basidiospores.

R.H.S.F. Cruz, J.J.S. Oliveira, UFRN-Fungos 1912; Brazil, Rio Grande do Norte, Baía Formosa, Reserva Particular do Patrimônio Natural Mata Estrela, 21 April 2010, M.M.B. Barbosa, T. Lockwood, I.G. Baseia, UFRN-Fungos 1449; Brazil, Pernambuco, Buíque, Vale do Catimbau, 04 April 2003, UFRN-Fungos 160; 16 April 2009, J.J.S. Oliveira, UFRN-Fungos 1035; 17 July 2009, J.J.S. Oliveira, UFRN-Fungos 1038.

Notes - Belongs to group VI - poeppigii (Brodie 1975) or striatum (Zhao et al. 2007). Cyathus limbatus is a recurring species in countries with a hot climate. The basidiospores of this species are commonly ellipsoid, but rare ovoid spores were observed in sample UFRN-Fungos 1932, in addition to peridioles with angular conformation, unlike the circular to irregular shape of other samples. Another variation was obtained in sample UFRN-Fungos 1449, where most of the basidiomata exhibited wooly exoperidium due to scraping by the voucher substrate. Cyathus limbatus was previously described for Northeastern Brazil by Trierveiler-Pereira \& Baseia (2009).

Cyathus pallidus Berk. \& M. A. Curtis, J. Linn. Soc., Bot. 10 (46): 346 (1869)

Figs 2G-2I

Peridium campanulate, 3-6 mm high, 3-5 $\mathrm{mm}$ wide at the mouth, expanding at the top but not tapering abruptly at the base; emplacement inconspicuous. Exoperidium hairy, brown (7E5), covered with a $0.5-1 \mathrm{~mm}$ tomentum, arranged in irregular and flexible tufts; external wall smooth. Mouth smooth. Endoperidium reddish grey (7B2), smooth to faintly plicate, slightly bright, not contrasting with the exterior. Stipe and epiphragm not obtained. Peridioles 1.5-2.2 × 1.4-1.7 mm, greyish brown (7F3), 8-9 per basidioma, angular to irregular in outline. Tunic indistinct. Cortex single layered. Basidiospores smooth, hyaline, subglobose to elliptical, rarely ovoid, without an apicule, 6.35-10.16 ×5-6.35 $\mu \mathrm{m}\left(\mathrm{L}=7.92 \mu \mathrm{m} ; \mathrm{W}=5.45 \mu \mathrm{m} ; \mathrm{Q}_{\mathrm{m}}=1.46\right)$, thin walled 1-1.27 $\mu \mathrm{m}$. 
Habitat and distribution - Grows in clusters on decaying wood and branches. Known from the American continent (White 1902, Lloyd 1906, Brodie \& Dennis 1954, Gómez \& Pérez-Silva 1988, Baseia \& Milanez 2001, Trierveiler-Pereira \& Baseia 2009) and China (Liu 1984).

Material examined - Brazil, Rio Grande do Norte, Baía Formosa, Reserva Particular do Patrimônio Natural Mata Estrela, 24 April 2004, I.G. Baseia, UFRN-Fungos 118.

Notes - C. pallidus is classified as group II - pallidus (Brodie 1975) or pallidum (Zhao et al. 2007). As indicated in $C$. berkeleyanus, this species can be easily confused with light and less plicate samples of $C$. berkeleyanus. Macroscopically, darker samples can be confused with $C$. microsporus Tul. \& C. Tul., but spore size can be used as a distinguishing feature [since $C$. microsporus spores are only $4 \mu \mathrm{m}$ wide (Brodie 1975), as opposed to 6-10 $\mu \mathrm{m}$ in C. pallidus]. According to Brodie (1975), it is a common species in the American tropics. Trierveiler-Pereira \& Baseia (2009) published a record of $C$. pallidus for Northeastern Brazil following a revision of the URM herbarium.

Cyathus poeppigii Tul. \& C. Tul., Ann. Sci. Nat., Bot., sér. 3 1: 77 (1844)

Figs 3A-3C

Peridium infundibulifom, 7-10 $\mathrm{mm}$ high, 4-6 $\mathrm{mm}$ wide at the mouth, expanding at the top but not tapering abruptly at the base; attached to the substrate by a conspicuous brown (5F7) emplacement, 1-1.5 $\mathrm{mm}$ in diameter. Exoperidium hairy, brown (5F7) to dark brown (5F8), covered with a $0.8-1 \mathrm{~mm}$ tomentum, arranged in irregular and flexible tufts; external wall faintly plicate, $0.3-0.4 \mathrm{~mm}$ between folds. Mouth fimbriated, $0.5 \mathrm{~mm}$, brown (5F7). Endoperidium brownish grey (5F2), conspicuously plicate, $0.3-0.4 \mathrm{~mm}$ between folds, slightly bright, not contrasting with the exterior. Stipe and epiphragm not visible. Peridioles $1.8-2.0 \mathrm{~mm} \times 1.2-1.8$ $\mathrm{mm}$, grey (4F1), 11 per basidioma, irregular to angular in outline. Tunic present, thin, hyaline, yellowish. Cortex double-layered. Basidiospores smooth, hyaline, elliptical to ovoid, apicule present in some spores, 25.4-47 × 15-24.13 $\mu \mathrm{m}\left(\mathrm{L}=34.21 \mu \mathrm{m} ; \mathrm{W}=21.04 \mu \mathrm{m} ; \mathrm{Q}_{\mathrm{m}}=1.64\right)$, thin walled $1-2.5 \mu \mathrm{m}$.

Habitat and distribution - Growing solitary on decaying branches and palm leaves. Known from the West Indies, America, Asia and Africa (Brodie 1975).

Material examined - Brazil, Pernambuco, Buíque, Vale do Catimbau, B.T. Goto, UFRNFungos 415.

Notes - Cyathus poeppigii belongs to the homonym group proposed by Brodie (1975) or striatum defined by Zhao et al. (2007) and is considered a recurring species in tropical climates, as C. striatus (Huds.) Willd. is for temperate climates (Lloyd 1906). Characteristically exhibits large spores and marked peridium, but with significant variation in spore size and shape, mainly in mycelial culture studies, as observed by Brodie (1955). It can be confused with C. limbatus under macroscopy, but C. limbatus spores do not exceed $25 \mu \mathrm{m}$ in length. Trierveiler-Pereira \& Baseia (2009) published the first record for the Northeast, but the studied material represent a sample from Southern Brazil deposited in the URM herbarium. Thus, it is considered the first record of $C$. poeppigii for Northeastern Brazil.

Cyathus setosus H.J. Brodie, Can. J. Bot. 45(1): 1 (1967)

Figs 3D-3F

Peridium broadly campanulate to infundibuliform, $8.5-11.5 \mathrm{~mm}$ high, $6.5-8.8 \mathrm{~mm}$ wide at the mouth, expanding at the top, sometimes tapering abruptly at the base; attached to the substrate by a conspicuous dark brown (8E4) emplacement, 2-4 $\mathrm{mm}$ in diameter. Exoperidium hairy, concolor to the emplacement, covered with a $0.7-0.9 \mathrm{~mm}$ tomentum, arranged in irregular and flexible tufts; external wall smooth to faintly plicate, $0.5-0.75 \mathrm{~mm}$ between folds. Mouth setose, 0.4-0.7 mm, dark brown (8E4). Endoperidium greyish brown (5E3), smooth to faintly plicate, 0.5$0.75 \mathrm{~mm}$ between folds, perceptibly bright contrasting with the exterior. Stipe and epiphragm not visible. Peridioles 1.5-2.5 × 1.5-2 mm, dark brown (9F4), 7-8 per basidioma, circular to angular in outline. Tunic indistinct. Cortex double layered. Basidiospores smooth, hyaline, elliptical, without an apicule, $13.97-17.78 \times 8-11.43 \mu \mathrm{m}\left(\mathrm{L}=15.98 \mu \mathrm{m} ; \mathrm{W}=9.93 \mu \mathrm{m} ; \mathrm{Q}_{\mathrm{m}}=1.62\right)$, thin walled 1-2.5 $\mu \mathrm{m}$. 


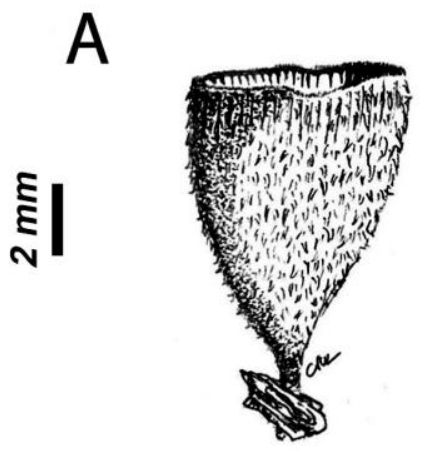

B
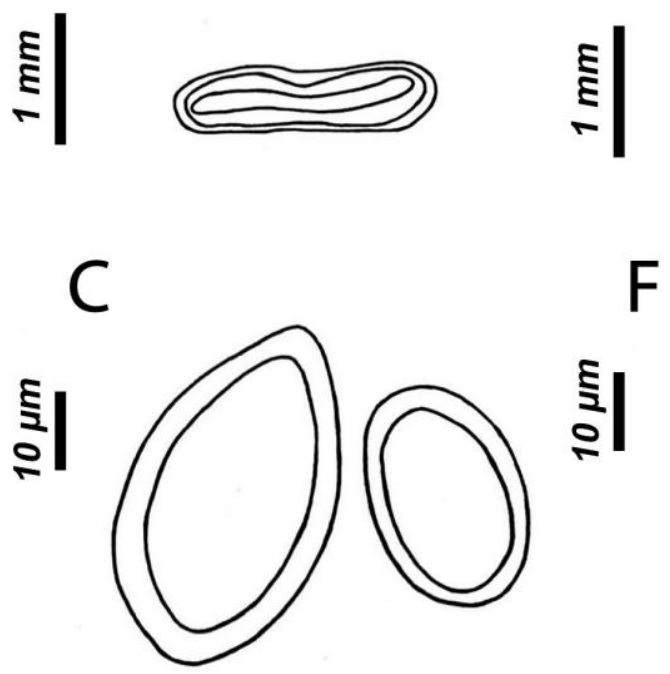
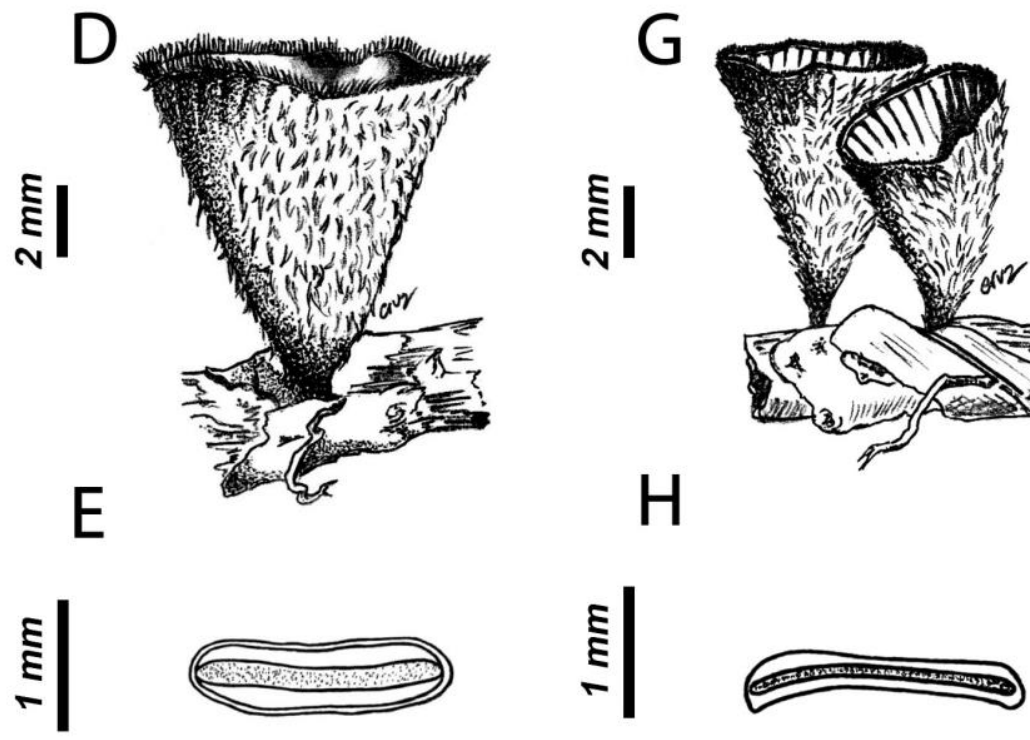

$\mathrm{H}$

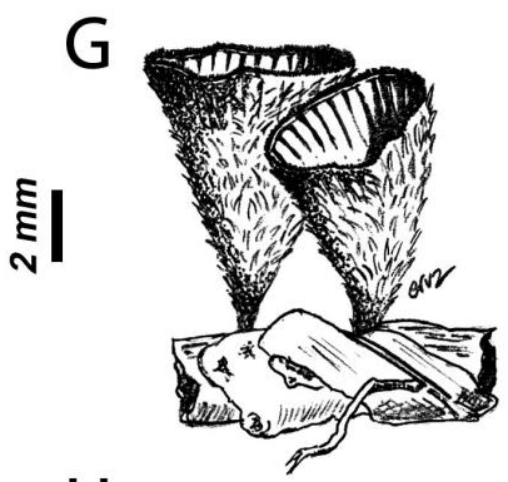

$\frac{5}{2}$

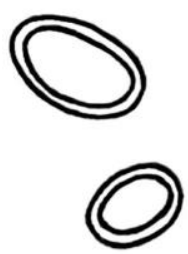

Figs 3 - A-C, Cyathus poeppigii: A, Basidiomata. B, Peridiole with double-layered cortex. C, Basidiospores. D-F, Cyathus setosus: D, Basidiomata. E, Peridiole with double-layered cortex. F, Basidiospores. G-H, Cyathus striatus: G, Basidiomata. H, Peridiole with single-layered cortex. I, Basidiospores.

Habitat and distribution - Grows solitary on decaying wood or in the ground. Known from Jamaica, St Lucia, Trinidad, Guadeloupe, Mexico, Bolivia (Brodie 1975) and Brazil (TrierveilerPereira \& Baseia 2013).

Material examined - Brazil, Rio Grande do Norte, Natal, Parque Estadual Dunas do Natal, 22 June 2005, B.D.B. Silva, A.G. Leite, I.G. Baseia, UFRN-Fungos 570; Brazil, Pernambuco, Igarassu, São José Factory, 08 October 2003, T.B. Gibertoni, UFRN-Fungos 402.

Notes - Belongs to group III - triplex, defined by Brodie (1975), but in an undefined position by Zhao et al. (2007); this species exhibits dark-brownish setae marking the edge of the peridium, in addition to a triangular and symmetrical shape, which places it between campanulate and infundibuliform. According to Brodie (1967), this species shows similarities to C. triplex Lloyd, $C$. montagnei Tul. \& C. Tul. and C. nigroalbus Lloyd, but the prominent setae, absence of tunic, as well as peridiole size and color distinguishes it from the others. It was recently described for Northeast Brazil by Trierveiler-Pereira \& Baseia (2013) in an Atlantic Forest area.

Cyathus striatus (Huds.) Willd., Fl. Berol. Prodr.: 399 (1787)

Figs 3G-3I

Peridium infundibuliform, 7-9 mm high, 4.5-6.5 $\mathrm{mm}$ wide at the mouth, not expanded at the top but sometimes slightly constricted at the base; attached to the substrate by an inconspicuous 
emplacement. Exoperidium hairy, reddish brown (9F7), covered with a $0.7 \mathrm{~mm}$ tomentum, arranged in regular and flexible upward facing tufts; external wall plicate, $0.5 \mathrm{~mm}$ between folds. Mouth fimbiate, $0.5 \mathrm{~mm}$, reddish brown (9F7). Endoperidium brown (5F5), faintly to conspicuously plicate, $0.5 \mathrm{~mm}$ between folds, slightly shiny but not contrasting with the exterior. Stipe and epiphragm not visible. Peridioles $2.1-2.8 \times 1.8-2.2 \mathrm{~mm}$, brownish grey (7E2), 10 per basidioma, irregular to circular in outline. Tunic present, hyaline. Cortex single layered. Basidiospores smooth, hyaline, elliptical, without an apicule, 12.7-19.05 × 9-12.7 $\mu \mathrm{m}$ (L = 16.85 $\mu \mathrm{m} ; \mathrm{W}=10.5 \mu \mathrm{m} ; \mathrm{Q}_{\mathrm{m}}=1.62$ ), thin walled 1-2.5 $\mu \mathrm{m}$.

Habitat and distribution - Grows in clusters on decaying wood or leaves. Known from America, Europe and Asia, with wide distribution in temperate regions (Brodie 1975), and numerous records in non-temperate countries such as Turkey, Venezuela, India, China (Brodie 1984) and Brazil (Rick 1961, Bononi et al. 1981, Baseia \& Milanez 2001, Meijer 2006, TrierveilerPereira \& Baseia 2009).

Material examined - Brazil, Ceará, Viçosa, 05 March 2005, R.S. Araújo, UFRN-Fungos 994; Brazil, Paraíba, Mamanguape, Reserva Biológica Guaribas, 17 October 1988, J.V.B. Silva, M.A. Sousa, JPB 7611; 17 October 1989, J.V.B. Silva, JPB 7611; Brazil, Bahia, Uruçaca, São José Farm, 02 October 2007, J.L. Bezerra, UESC 868; Ilhéus, Cepec-Matinha, 02 December 2008, J.L. Bezerra, UESC 1597.

Notes - Belongs to the homonym group defined by Brodie (1975) or the striatum group proposed by Zhao et al. (2007). Cyathus striatus is widely distributed in temperate regions, but there are also records in various non-temperate South American countries such as Brazil and Venezuela. Characterized by a well-marked dark peridium, both internally and externally, this species is recurrent for Brazilian Atlantic Forest areas and was previously described for the Northeast by Trierveiler-Pereira \& Baseia (2009).

\section{Acknowledgements}

We are grateful to the curators Dr. Maria Regina de Vasconcellos Barbosa (JPB herbarium), Dr. Luciano Paganucci de Queiroz (UESC herbarium) and Dr. Leonor Costa Maia (URM herbarium), for providing access to the exsiccates. To Dr. Felipe Wartchow, Dr. José Luiz Bezerra, MSc. Mariana Cavalcante Almeida Sá and Altielys Casale Magnago MSc. who facilitated the contact with these herbaria. The first and third authors would like to thank CAPES (Coordination for the Improvement of Higher Education Personnel, Brazil), and the second author would like to thank CNPq (National Council for Scientific and Technological Development) for financial support.

\section{References}

Barbosa MMB, Cruz RHSF, Calonge FD, Baseia IG. 2014 - Two new records of Cyathus species for South America. Mycosphere 5, 425-428.

Baseia IG, Milanez AI. 2001 - Cyathus (Gateromycetes) in Areas of the Brazilian Cerrado region, São Paulo State. Mycotaxon 80, 493-502.

Bononi VLR, Guzmán G, Capelari M. 1984 - Basidiomicetos do Parque Estadual da Ilha do Cardoso V: Gasteromicetos. Rickia 11, 91-97.

Bononi VLR, Trufen SFB, Grandi RAP. 1981 - Fungos Macroscópicos do Parque Estadual das Fontes do Ipiranga depositados no Herbário do Instituto de Botânica. Rickia 9, 37-53.

Bottomley AM. 1948 - Gasteromycetes of South Africa. Bothalia 4, 473-810.

Brock PM, Döring H, Bidartondo MI. 2009 - How to know unknown fungi: the role of a Herbarium. New Phytologist 181, 719-724.

Brodie HJ. 1955 - Morphology and Culture Characteristics of a Highly Aberrant Cyathus. American Journal of Botany 42, 168-176.

Brodie HJ. 1967 - Cyathus setosus, a new member of the Nidulariaceae from Jamaica. Canadian Journal of Botany 45, 1-3. 
Brodie HJ. 1975 - The Bird's Nest Fungi. Canada. Uniiversity of Toronto Press.

Brodie HJ. 1984 - More Bird's Nest Fungi (Nidulariaceae) - A supplement to "The Bird's Nest Fungi” (1975). Lejeunia Revue de Botanique, Nouvelle série no 112.

Brodie HJ, Dennis RWG. 1954 - The Nidulariaceae of the West Indies. Transactions British Mycological Society 37, 151-160.

Cruz RHSF, Barbosa MMB, Baseia IG. 2012 - Cyathus badius and C. earlei reported from Brazilian Atlantic rainforest. Mycotaxon 121, 365-369.

Meijer AAR. 2006 - Preliminary list of macromycetes from the Brazilian State of Paraná. Boletim do Museu Botânico Municipal 68, 1-55.

Fogel R. 1998 - A revised mission for fungal Herbaria. Inoculum: Newsletter of the Mycological Society of America. Supplement to Mycologia 49 (6).

Gómez CL, Pérez-Silva E. 1988 - Especies de Nidulariales (Gasteromycetes) comunes em Mexico. Revista Mexicana de Micologia 4, 161-183.

Kirk PM, Cannon PF, Minter DW, Stalpers JA. 2008 - Ainsworth \& Bisbys's Dictionary of the Fungi. 10th ed. CAB International, Wallinford.

Kornerup A, Wanscher JE. 1978 - Methuen Handbook of Colour. 3rd ed. London, Methuen.

Kobayasi Y. 1937 - Fungi austro-japoniae et micronesiae, I. Botanical Magazine Tokyo 51, 749758.

Liu B. 1984 - The Gasteromycetes of China. Beiheftezur, Nova Hedwigia 74, 1-235.

Liu B, Li YM. 1989 - New species new variety and new record of the genus Cyathus from China. Acta Mycologica Sinica 8, 289-295.

Lloyd CG. 1906 - The Nidulariaceae or "Bird's-Nest Fungi". Cincinnati.

Matheny PB, Curtis JM, Hofstetter V, Aime MC, Moncalvo JM, Ge ZW, Yang ZL, Slot JC, Ammirati JF, Baroni TJ, Bougher NL, Hughes KW, Lodge DJ, Kerrigan RW, Seidl MT, Aanen DK, DeNitis M, Daniele GM, Desjardin DE, Kropp BR, Norvell LL, Parker A, Vellinga EG, Vilgalys R, Hibbett DS. 2006 - Major clades of Agaricales: a multilocus phylogenetic overview. Mycologia 98, 982-995.

Rick J. 1961 - Basidiomycetes Eubasidii no Rio Grande do Sul. Iheringia 9, 451-480.

Thiers B. 2013 - Index Herbariorum: a global directory of public herbaria and associated staff. New York Botanical Garden's Virtual Herbarium. http://sweetgum.nybg.org/ih/ (accessed July 2013)

Trierveiler-Pereira L, Baseia IG. 2009 - Revision of the Herbarium URM IV. Nidulariaceae (Basidiomycota). Nova Hedwigia 89, 361-369.

Trierveiler-Pereira L, Baseia IG. 2013 - Cyathus species (Basidiomycota: Fungi) from the Atlantic Forest of Pernambuco, Brazil: taxonomy and ecological notes. Revista Mexicana de Biodiversidad 84, 1-6.

White VS. 1902 - The Nidulariaceae of North America. Bulletin of the Torrey Botanical Club 29, 251-280.

www.indexfungorum.org -2013.

Zhao RL, Desjardin DE, Soytong K, Hyde KD. 2008 - A new species of bird's nest fungi: characterization of Cyathus subglobisporus sp. nov. based on morphological and molecular data. Persoonia 21, 71-76.

Zhao RL, Jeewon R, Desjardin DE, Soytong K, Hyde KD. 2007 - Ribosomal DNA phylogenies of Cyathus: Is the current infrageneric classification appropriate? Mycologia 99, 385-395. 